Novel Insights from Clinical Practice

\title{
Fetal Goitrous Hypothyroidism due to Maternal Thyroid Stimulation-Blocking Antibody: A Case Report
}

Satoshi Ohira ${ }^{\mathrm{a}}$, Masako Miyake ${ }^{\mathrm{a}}$, Hisanori Kobara ${ }^{\mathrm{a}}$, Norihiko Kikuchi ${ }^{\mathrm{a}}$, Ryosuke Osada ${ }^{\mathrm{a}}$, Takashi Ashida $^{\mathrm{a}}$, Kanae Hirabayashi ${ }^{\mathrm{b}}$, Shin-ichi Nishio ${ }^{\mathrm{c}}$, Makoto Kanai ${ }^{\mathrm{a}}$, and Tanri Shiozawa $^{\mathrm{a}}$

${ }^{\mathrm{a}}$ Department of Obstetrics and Gynecology, ${ }^{\mathrm{b}}$ Department of Pediatrics, and ${ }^{\mathrm{c}}$ Department of Aging Medicine and Geriatrics, Shinshu University School of Medicine, Matsumoto, Japan

3-1-1 Asahi, Matsumoto 390-8621, Japan

Running title: Fetal Goitrous Hypothyroidism

\section{Address correspondence and reprint requests to:}

Tanri Shiozawa, M.D. Department of Obstetrics and Gynecology, Shinshu University

School of Medicine, 3-1-1 Asahi, Matsumoto 390-8621, Japan

FAX: +81-263-34-0944; TEL: +81-263-37-2719

e-mail: tanri@shinshu-u.ac.jp 


\section{Highlighted boxes}

\section{Established Facts}

- Evidence has accrued of the transplacental passage of thyroid stimulation-blocking antibody (TSBAb) as a cause of transient hypothyroidism in neonates.

\section{Novel Insight}

- There have been no reports of any relation between a fetal goiter and TSBAb. We report an extremely rare case of fetal goitrous hypothyroidism caused by the transplacental passage of maternal TSBAb. 
Key Words: congenital hypothyroidism, fetal goiter, maternal hypothyroidism, thyroid stimulation-blocking antibody, transplacental passage

\begin{abstract}
Most fetal goitrous hypothyroidisms are reportedly caused by the maternal use of an antithyroid drug or fetal dyshormonogenesis. However, fetal goitrous hypothyroidism due to the transplacental passage of maternal thyroid stimulation-blocking antibody (TSBAb) is extremely rare. A woman at 28 weeks of gestation was found to have a fetal goiter by ultrasonography. Because the maternal serum showed hypothyroidism with an elevated titer of TSBAb, levothyroxine sodium was administered. The patient delivered a male 3412-g infant with a goiter at term. Umbilical blood revealed primary hypothyroidism with increased TSBAb, and the infant took levothyroxine sodium. After a month, neonatal thyroid function and TSBAb levels became normal. Attention should be paid to possible fetal hypothyroidism when a fetal goiter is observed to avoid impaired mental development of the neonate.
\end{abstract}




\section{Introduction}

Auto-antibodies against thyroid-stimulating hormone (TSH) receptors are known to play important roles in autoimmune thyroid disorders. Thyroid-stimulating antibody (TSAb), an immunoglobulin that stimulates thyroid function, is most often detected in patients with Graves' disease. Fetuses and neonates with transient hyperthyroidism due to the placental transfer of TSAb are usually born to mothers with a history of hyperthyroid Grave's disease [1]. In contrast, thyroid stimulation-blocking antibody (TSBAb), which inhibits thyroid function, is mainly detected in patients with atrophic autoimmune thyroiditis. Since 1980, evidence has accrued of the transplacental passage of TSBAb as a cause of transient hypothyroidism in neonates [1, 2]. However, there have been no reports of any association with a fetal goiter in neonates. We report an extremely rare case of fetal goitrous hypothyroidism caused by the transplacental passage of maternal TSBAb.

\section{Case Report}

A 37-year-old gravida 3 para 1 pregnant woman was referred to our hospital at 28 weeks and 0 days of gestation because of a large fetal neck mass detected by ultrasonography. A bilobed symmetrical solid mass measuring $4.2 \mathrm{~cm}$ was identified in the anterior aspect of the fetal neck (Fig. 1a). The mass was highly vascular and did not extend retrosternally (Fig. 1b). Fetal growth and amniotic fluid volume appeared normal. Fetal magnetic resonance imaging (MRI) revealed the mass to surround the fetal trachea, suggestive of a fetal goiter (Fig. 2). Although the patient had no history of thyroid disease, her thyroid was swollen. Serum TSH levels were markedly elevated (9.45 $\mu \mathrm{IU} / \mathrm{ml}$, normal: $0.20-4.00 \mu \mathrm{IU} / \mathrm{ml}$ ) but serum levels of free thyroxine ( $\mathrm{fT}_{4}$ ) were decreased $(0.80 \mathrm{ng} / \mathrm{dl}$, normal: $1.00-2.00 \mathrm{ng} / \mathrm{dl})$. Those of thyroglobulin antibody (TgAb) and thyroid peroxidase antibody (TPOAb) were $1.3 \mathrm{IU} / \mathrm{ml}$ and $0.8 \mathrm{IU} / \mathrm{ml}$, respectively (normal: $<10.0 \mathrm{IU} / \mathrm{ml}$ ). Although the TSAb titer was within a normal range at $118 \%$ (normal: $<180 \%$ ), the TSBAb titer was elevated at $51.9 \%$ (normal $<45.6 \%$ ). Although the possibility of fetal hypothyroidism was suspected, fetal blood sampling by cordocentesis was not performed because informed consent was not obtained. Therefore, the administration of $50 \mu \mathrm{g} /$ day of oral levothyroxine sodium $\left(\mathrm{L}-\mathrm{T}_{4}\right)$ was immediately started for the management of maternal hypothyroidism.

In order to attempt to drive more L-T4 across the placenta, the maternal dose of $\mathrm{L}-\mathrm{T}_{4}$ was gradually increased up to $125 \mu \mathrm{g} /$ day at 36 weeks of gestation and maternal thyroid function eventually became normal (TSH: $1.33 \mu \mathrm{IU} / \mathrm{ml}, \mathrm{fT}_{4}: 1.22 \mathrm{ng} / \mathrm{dl}$ ). The patient went into an active labor at 41 weeks and 3 days of gestation, and delivered a 
male infant weighing $3412 \mathrm{~g}$ with Apgar scores of 8 and 9 at 1 and 5 min., respectively. Although no evidence of neonatal airway obstruction was seen, an enlarged thyroid was present (Fig. 3). Serum levels of TSH and $\mathrm{fT}_{4}$ in the umblilical blood were 113.4 $\mu \mathrm{IU} / \mathrm{ml}$ and $0.71 \mathrm{ng} / \mathrm{dl}$, respectively, consistent with primary hypothyroidism. The neonatal serum TSBAb titer also showed an increase, at $49.9 \%$. Other neonatal serum antibodies related to thyroid were not elevated. The epiphysis of the distal femur was visible on X-ray film. The infant was started on $25 \mu \mathrm{g}$ daily oral $\mathrm{L}_{-} \mathrm{T}_{4}$, and the goiter gradually became smaller. A month after birth, neonatal serum thyroid function and TSBAb levels were within normal limits (TSH: $0.45 \mu \mathrm{IU} / \mathrm{ml}$, TSBAb: $45.5 \%$ ). Oral L-T 4 was continued until 22 months, and follow-up examination at 26 months revealed that the infant was well and developmentally normal.

\section{Comment}

Transient hypothyroidism in the neonate due to maternal TSBAb is a rare condition, with the incidence in North America being 1 in 180,000 normal infants, or approximately $2 \%$ of babies with congenital hypothyroidism [3]. Since Matsuura et al. first described two siblings and a mother with this disorder in 1980 [2], a total of 16 maternal and 26 neonatal cases have been reported [2, 4-11]. Although affected infants do not require lifelong therapy, there is a high rate of recurrence in subsequent offspring due to the TSBAb persisting for years in the maternal circulation. Francis and Riley reported congenital familial transient hypothyroidism in three siblings due to maternal TSH-blocking antibodies detected after the last pregnancy [8].

The most peculiar finding of the present case is the solid mass within the fetal neck. Fetal goiters can be associated with both fetal hyperthyroidism and hypothyroidism. Our search of the literature found a total of 39 cases of fetal goiter [12-25], which we classified into three patterns regarding the relation to maternal-fetal thyroid function (Table 1). The first pattern is maternal hyperthyroidism and fetal goitrous hypothyroidism influenced by the excessive placental transfer of maternal antithyroid drugs. The second pattern is a maternal euthyroid state (no thyroid disease) and fetal goitrous hypothyroidism due to a defect in the biosynthesis of hormone in the fetal thyroid gland. In these two patterns, goiters are reportedly caused by increased secretion of TSH in response to a metabolic block of thyroid hormone synthesis [19], as the TSH stimulates the proliferation of human thyroid cells, acting through cyclic AMP [26]. The third pattern is maternal hyperthyroidism and fetal goitrous hyperthyroidism influenced by the placental transfer of maternal TSAb. The current case involves maternal hypothyroidism and fetal goitrous hypothyroidism influenced by the placental 
transfer of maternal TSBAb, being different from the previous three patterns. In general, most individuals with high titers of TSBAb would be expected to have an atrophic thyroid gland and non-goitrous hypothyroidism, because most likely the TSBAb inhibits not only the thyroidal biosynthetic action but also the thyroid growth-promoting action of TSH [5]. Although one case report indicated a maternal goiter with TSBAb, the case was not associated with a fetal goiter [8]. Therefore, to our knowledge, this is the first report of fetal goitrous hypothyroidism caused by maternal TSBAb. Although why the goiter formed is unclear, we speculate that both the maternal and fetal goiters were caused by the strong thyroid growth-promoting action of an exceptionally elevated level of TSH.

In the current case, the infant was started on $25 \mu \mathrm{g}$ daily oral L-T $4(7.32 \mu \mathrm{g} / \mathrm{kg})$. Because the goal of therapy is to normalize TSH within one month, and a dosage of 10 to $15 \mu \mathrm{g} / \mathrm{kg}$ of L-T 4 has been recommended [27], we had intended to increase the dose of L-T 4 up to 10 to $15 \mu \mathrm{g} / \mathrm{kg}$. However a month after birth, our neonatal serum thyroid function was within normal limits, therefore, the dose of $\mathrm{L}_{-} \mathrm{T}_{4}$ was not increased.

Although it is usually expected that the neonatal TSBAb become negative approximately 12 weeks after birth, our neonatal serum TSBAb levels became within normal limits one month after birth. Since the maternal and transplacental neonatal antibodies against TSH receptors are significantly correlated [28], the reason of early decrease of neonatal TSBAb might be that the elevated titer of maternal TSBAb was not so severe. Because the administration of $\mathrm{L}_{-} \mathrm{T}_{4}$ was not needed permanently, we finally considered that primary hypothyroidism in our neonate was caused by the transplacental passage of maternal TSBAb, not by a defect in the biosynthesis of thyroid hormone.

Both fetal hypothyroidism and hyperthyroidism can potentially affect the growth of fetuses and neonates, but, fetal hypothyroidism seems to be a more severe condition in terms of fetal mental development [29]. In several cases of fetal goiter, the diagnosis of congenital hypothyroidism was made by fetal blood sampling via cordcentesis, and subsequent intrauterine treatment with intra-amniotic $\mathrm{L}_{-} \mathrm{T}_{4}$ administrations was initiated at third trimester $[13,23]$. Therefore, an immediate assessment of fetal thyroid function is preferable when a maternal abnormality of thyroid function or fetal goiter is detected. Although maternal TSBAb-induced hypothyroidism with a fetal goiter and fetal hypothyroidism is rare, the present case may warrant the need for the adequate evaluation and treatment of fetal goiter.

\section{REFERENCES}


1. McKenzie JM, Zakarija M: Fetal and neonatal hyperthyroidism and hypothyroidism due to maternal TSH receptor antibodies. Thyroid 1992;2:155-159.

2. Matsuura N, Yamada Y, Nohara Y, Konishi J, Kasagi K, Endo K, Kojima H, Wataya $\mathrm{K}$ : Familial neonatal transient hypothyroidism due to maternal TSH-binding inhibitor immunoglobulins. N Engl J Med 1980;303:738-741.

3. Brown RS, Bellisario RL, Botero D, Fournier L, Abrams CAL, Cowger ML, David R, Fort P, Richman RA: Incidence of transient congenital hypothyroidism due to maternal thyrotropin receptor-blocking antibodies in over one million babies. J Clin Endocrinol Metab 1996;81:1147-1151.

4. Iseki M, Shimizu M, Oikawa T, Hojo H, Krikawa K, Ichikawa Y, Momotani N, Ito K: Sequential serum measurements of thyrotropin binding inhibitor immunoglobulin $\mathrm{G}$ in transient familial neonatal hypothyroidism. J Clin Endocrinol Metab 1983;57:384-387.

5. Takasu N, Mori T, Koizumi Y, Takeuchi S, Yamada T: Transient neonatal hypothyroidism due to maternal immunoglobulins that inhibit thyrotropin-binding and post-receptor processes. J Clin Endocrinol Metab 1984;59:142-146.

6. Ishihara T, Waseda N, Ikekubo K, Kuroda K, Akamizu T, Mori T: A predicted case with neonatal transient hypothyroidism due to blocking type thyrotropin binding inhibitor immunoglobulins (TBII). Endocrinol Japon 1985;32:189-194.

7. Inomata H, Sasaki N, Tamaru K, Ushiku H, Niimi H, Nakajima H: Relationship between potency of blocking type thyrotropin-binding inhibitor immunoglobulin in three women with primary myxedema and thyroid function of their neonates. Endocrinol Japon 1986;33:353-359.

8. Francis G, Riley W: Congenital familial transient hypothyroidism secondary to transplacental thyrotropin-blocking autoantibodies. Am J Dis Child 1987;141:1081-1083.

9. Matsuura N, Konishi J, Harada S, Yuri K, Fujieda K, Kasagi K, Iida Y, Fujimoto S, Fukushi M, Takasugi N: The prediction of thyroid function in infants born to mothers with chronic thyroiditis. Endocrinol Japon 1989;36:865-871.

10. Matsuura N, Konishi J: Transient Hypothyroidism Study Group in Japan: Transient hypothyroidism in infants born to mothers with chronic thyroiditis: a nationwide study of twenty-three cases. Endocrinol Jpn 1990;37:369-379.

11. Pacaud D, Huot C, Gattereau A, Brown RS, Glorieux J, Dussault JH, Van Vliet G: Outcome in three siblings with antibody-mediated transient congenital hypothyroidism. J Pediatr 1995;127:275-277.

12. Grüner C, Kollert A, Wildt L, Dörr HG, Beinder E, Lang N: Intrauterine treatment of 
fetal goitrous hypothyroidism controlled by determination of thyroid-stimulating hormone in fetal serum. Fetal Diagn Ther 2001;16:47-51.

13. Polak M, Leger J, Luton D, Oury JF, Vuillard E, Boissinot C, Czernichow P: Fetal cord blood sampling in the diagnosis and the treatment of fetal hyperthyroidism in the offsprings of a euthyroid mother, producing thyroid stimulating immunoglobulins. Ann Endocrinol 1997;58:338-342.

14. Heckel S, Favre R, Schlienger JL, Soskin P: Diagnosis and successful in utero treatment of a fetal goitrous hyperthyroidism caused by maternal Graves' disease: a case report. Fetal Diagn Ther 1997;12:54-58.

15. Friedland DR, Rothschild MA: Rapid resolution of fetal goiter associated with maternal Grave's disease: a case report. Int J Pediatr Otorhinolaryngol 2000;54:59-62.

16. Bellini P, Marinetti E, Arreghini A, Andreotti C, Kirm V, Roncaglia N: Treatment of maternal hyperthyroidism and fetal goiter. Minerva Ginecol 2000;52:25-27.

17. Perrotin F, Sembely-Taveau C, Haddad G, Lyonnais C, Lansac J, Body G: Prenatal diagnosis and early in utero management of fetal dyshormonogenetic goiter. Eur J Obstet Gynecol Reprod Biol. 2001;94:309-314.

18. Morine M, Takeda T, Minekawa R, Sugiyama T, Wasada K, Mizutani T, Suehara N: Antenatal diagnosis and treatment of a case of fetal goitrous hypothyroidism associated with high-output cardiac failure. Ultrasound Obstet Gynecol 2002;19:506-509.

19. Agrawal P, Ogilvy-Stuart A, Lees C: Intrauterine diagnosis and management of congenital goitrous hypothyroidism. Ultrasound Obstet Gynecol 2002;19:501-505.

20. Polak M, Le Gac I, Vuillard E, Guibourdenche J, Leger J, Toubert ME, Madec AM, Oury JF, Czernichow P, Luton D: Fetal and neonatal thyroid function in relation to maternal Graves'disease. Best Pract Res Clin Endocrinol Metab 2004;18:289-302.

21. Yanai N, Shveiky D: Fetal hydrops, associated with maternal propylthiouracil exposure, reversed by intrauterine therapy. Ultrasound Obstet Gynecol 2004;23:198-201.

22. Börgel K, Pohlenz J, Holzgreve W, Bramswig JH: Intrauterine therapy of goitrous hypothyroidism in a boy with a new compound heterozygous mutation (Y453D and C800R) in the thyroid peroxidase gene: a long-term follow-up. Am J Obstet Gynecol 2005;193:857-858.

23. Miyata I, Abe-Gotyo N, Tajima A, Yoshikawa H, Teramoto S, Seo M, Kanno K, Sugiura K, Tanaka T, Eto Y: Successful intrauterine therapy for fetal goitrous hypothyroidism during late gestation. Endocr J 2007;54:813-817. 
24. Hanono A, Shah B, David R, Buterman I, Roshan D, Shah S, Lam L, Timor-Tritsch I: Antenatal treatment of fetal goiter: a therapeutic challenge. J Matern Fetal Neonatal Med 2008;13:1-5.

25. Göktolga U, Karaşahin KE, Gezginç K, Fidan U, Ergün A, Başer I: Intrauterine fetal goiter: diagnosis and management. Taiwan J Obstet Gynecol 2008;47:87-90.

26. Collins SL: Etiopathogenesis of thyroid cancer; in Falk SA (ed): Thyroid Disease: Endocrinology, Surgery, Nuclear Medicine, and Radiotherapy. New York, Raven Press, 1990, pp 401-471.

27. American Academy of Pediatrics, Section on Endocrinology and Committee on Genetics, American Thyroid Association, Public Health Committee, Lawson Wilkins Pediatric Endocrine Society: Update of newborn screening and therapy for congenital hypothyroidism. Pediatrics 2006;117:2290-2303.

28. Sasaki N, Ohnishi T, Sato H, Wataki K, Tamaru K, Tsuyusaki T, Inomata H, Miyaji T, Niimi H: Measurement of TSH receptor antibody in pregnant women with Graves' disease predicts thyroid function of the newborn. Clin Pediatr Endocrinol 1998;7:111-114.

29. Gorieux J, Dussault J, Van Vliet G: Intellectual development at age 12 years in children with congenital hypothyroidism diagnosed by neonatal screening. J Pediatr 1992;121:581-584. 
Figure legends

Figure 1: Ultrasonography at 28 weeks of gestation. (a) a bilobed symmetrical solid mass measuring $4.2 \mathrm{~cm}$ was identified in the anterior aspect of the fetal neck (arrow); (b) Power Doppler scan revealed the mass to be highly vascular.

Figure 2: T2-weighted transverse image of fetal MRI. The mass surrounded the fetal trachea. Arrow indicates the trachea.

Figure 3: Infant's facial appearance shortly after birth, with enlarged thyroid gland. 
Table 1 Fetal goiter: its relation with maternal-fetal thyroid function

\begin{tabular}{lcll}
\hline $\begin{array}{l}\text { Maternal } \\
\text { function }\end{array}$ & $\begin{array}{c}\text { Fetal } \\
\text { function }\end{array}$ & Primary factor & $\begin{array}{c}\text { Number of } \\
\text { reported cases }\end{array}$ \\
\hline Hyper & Hypo & Transfer of maternal antithyroid drug & 19 cases $^{12,13,16,20,21,23}$ \\
Euthyroid & Hypo & Fetal dyshormonogenesis & 13 cases $^{12,17-19,22,24,25}$ \\
Hyper & Hyper & Transfer of maternal TSAb & 7 cases $^{14,15,20}$ \\
Hypo & Hypo & Transfer of maternal TSBAb & None (current case) \\
\hline
\end{tabular}

Hyper, hyperthyroidism; Hypo, hypothyroidism; TSAb, thyroid stimulating antibody;

TSBAb, thyroid stimulation-blocking antibody 
Ohira et al.
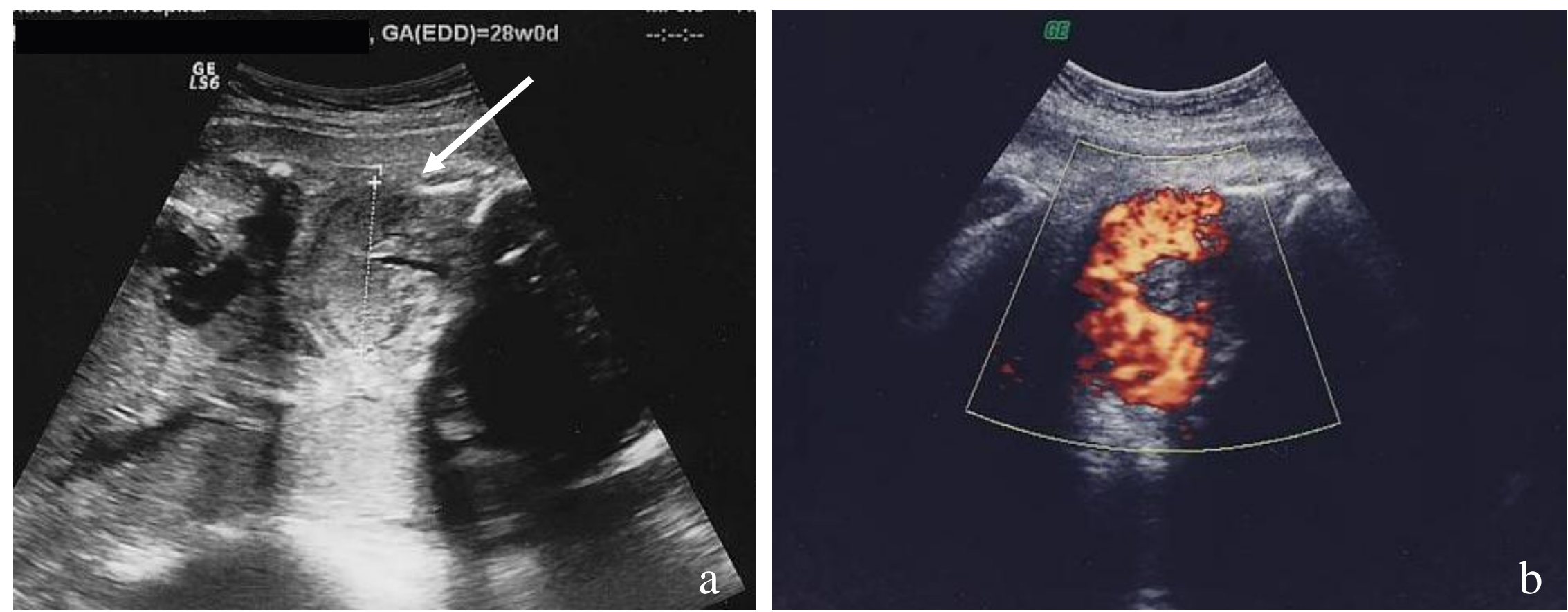

Figure 1 
Ohira et al.

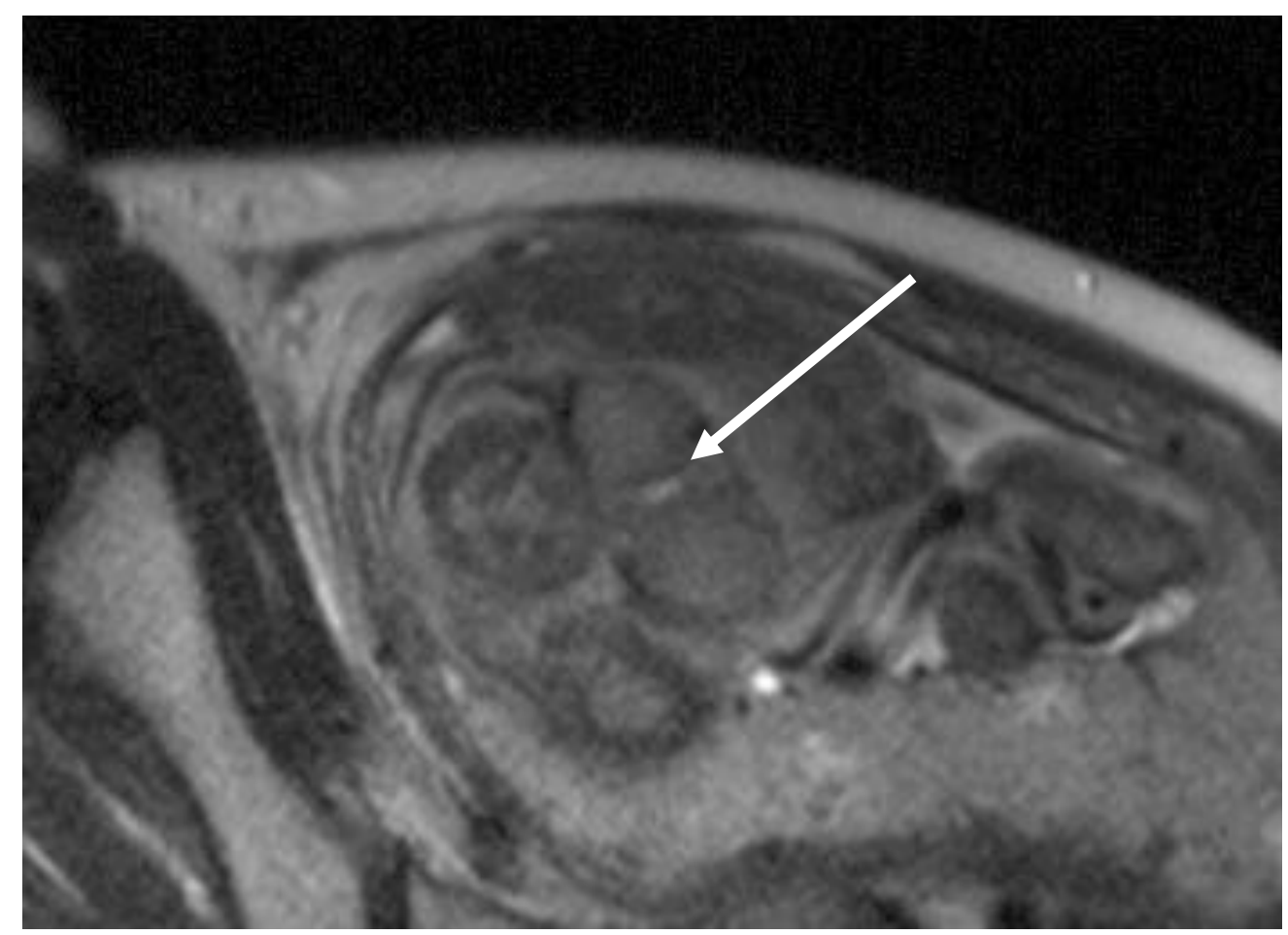

Figure 2 
Ohira et al.

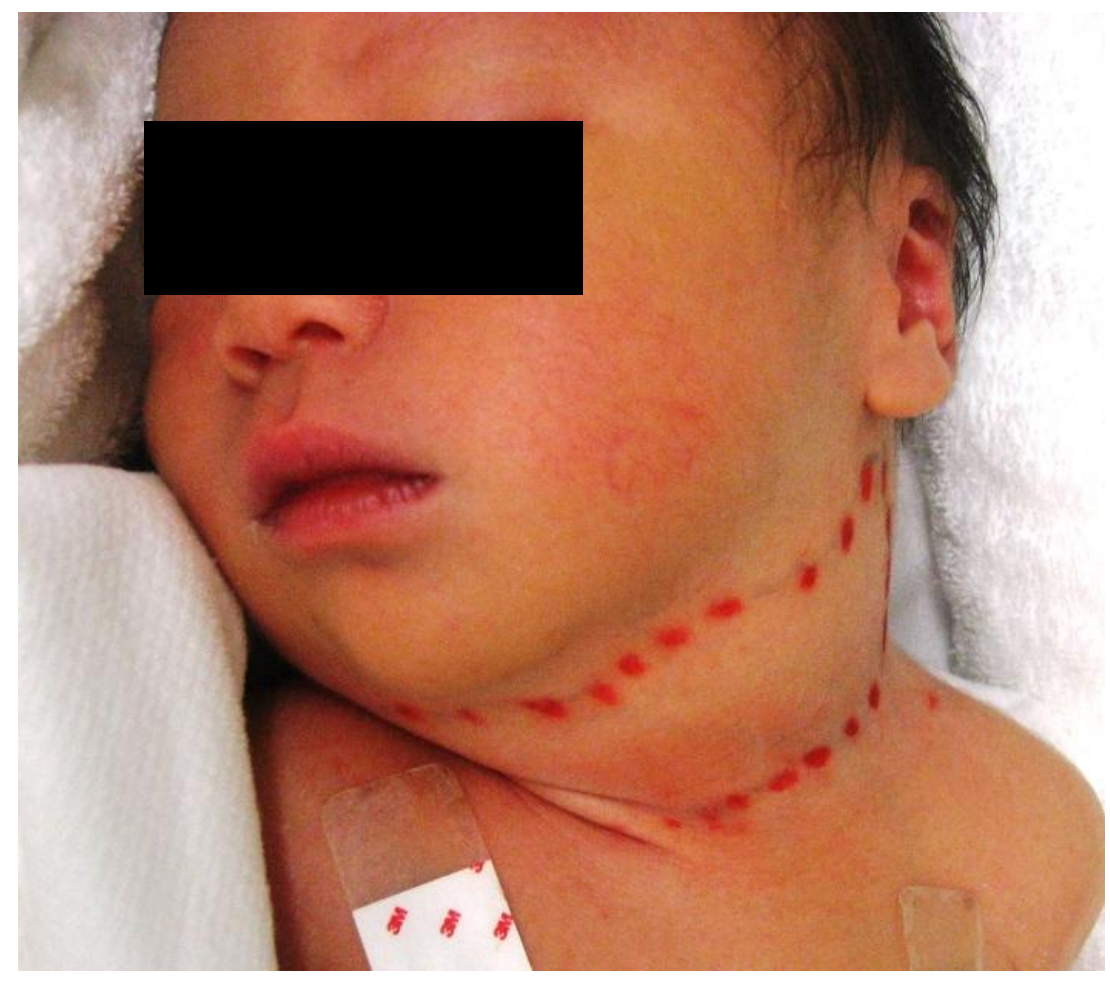

Figure 3 